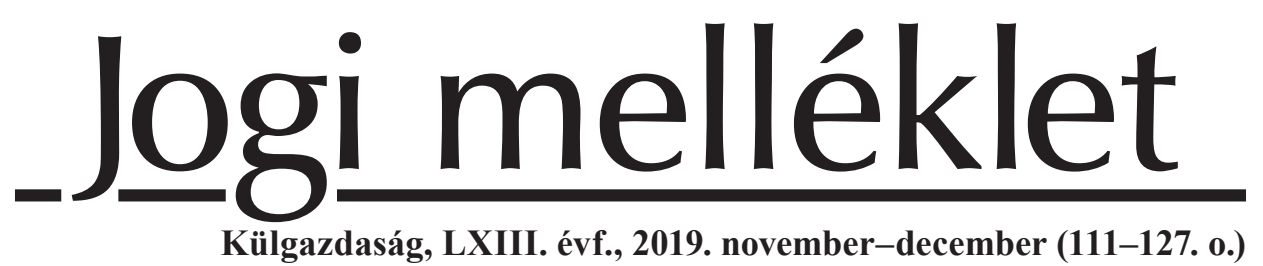

\title{
Az Európai Unió és az Egyesült Királyság kereskedelmi jogi kapcsolatrendszere a brexit után HORVÁTHY BALÁZS
}

Az Európai Unió és az Egyesült Királyság tárgyalói 2019 öszén módositották a brexitre vonatkozó feltételeket annak érdekében, hogy sikeresen le lehessen zárni a brit parlamentben a kilépési szerzödés megerösitését. Figyelembe véve a 2019. decemberben megtartott általános választások eredményeit is, ma már bizonyos, hogy az Egyesült Királyság e feltételek között fogja elhagyni az Európai Uniót 2020. január 31-ig. A cikk e feltételrendszer szükebb, kereskedelmi jogi összefüggéseire fókuszál. Célja annak bemutatása, hogy egyrészt milyen szerepet játszottak a kereskedelmi jogi megfontolások a kilépési tárgyalásokon, másrészt hogy a kilépést követöen milyen feltételek szerint határozza majd meg a kilépési megállapodás az Európai Unió és az Egyesült Királyság közötti kereskedelmi forgalmat. A cikkben a szerzö ismerteti azokat fontosabb kereskedelmi jogi normákat, amelyek az átmeneti idöszakban lesznek irányadók, külön kitér az Észak-Írországra alkalmazandó speciális szabályokra, valamint azokra a föbb elvekre, amelyek a jövőbeni, hosszú távú kapcsolatrendszer szempontjából lehetnek meghatározók.

Journal of Economic Literature (JEL) kód: F15 Economic Integration, F10 General, F53 International Agreements and Observance, K20 General, K39 Other.

https://doi.org/10.47630/KULG.2019.63.11-12.111

Horváthy Balázs, tudományos munkatárs (Társadalomtudományi Kutatóközpont - MTA Kiválósági Kutatóhely Jogtudományi Intézete). E-mail: horvathy.balazs@tk.mta.hu. 


\section{Bevezető}

A cikk lezárásakor vált ismertté az Egyesült Királyságban 2019. december 12én megtartott általános választások eredménye. A konzervatívok fölényes - a 80-as évek óta nem látott - győzelme után már nem kétséges, hogy a brexit fináléjához érkezve Boris Johnson vezetheti ki az Egyesült Királyságot az Európai Unióból. Ezzel lezárul az a többéves dráma, amely David Cameron 2013-ban megfogalmazott népszavazási ígéretével vette kezdetét és az elmúlt években az állandó bizonytalanság állapotát fenntartva feldúlta a brit belpolitikát, nyomot hagyott a több száz éves brit alkotmányos rendszeren és egyelöre még meg sem becsülhető, mekkora sebet ejtett az európai integrációs együttmüködés folyamatán.

Jelen írásnak nem tárgya az átfogó számvetés, csak egyetlen szűk aspektust, a kereskedelmi jogi összefüggéseket vizsgálja, és célja annak szemleszerü felvázolása, hogy a brit kiválást követően a kilépési megállapodás milyen feltételek mellett határozza majd meg az Európai Unió és az Egyesült Királyság közötti kereskedelmi forgalmat. A tanulmány elsőként a kilépési szerződéshez vezető út általános kérdéseit érinti (2. A Bloomberg-beszéd terhes öröksége), ezt követően vizsgálja, hogy a kilépési tárgyalásokon milyen módon közelítettek a felek a kereskedelmi kapcsolatrendszer rendezéséhez (3. A kilépési folyamat és a kilépési megállapodás), majd a kilépési megállapodás főbb kereskedelmi rendelkezéseit mutatja be (4. A kilépési megállapodás kereskedelmi rendelkezései), végül az írás következtetésekkel zárul (5. Záró megjegyzések).

\section{A Bloomberg-beszéd terhes öröksége}

Ha vissza lehetne fordítani az idő kerekét és keresnénk az Egyesült Királyság Európai Unióból történő kilépésének előtörténetében azt a pontot, mikor még teljes egészében megelőzhető lett volna az a fordulatokban bővelkedő folyamat, amely az elmúlt években brexitként tárult elénk, vélhetően legalább 2013 elejére kellene visszautaznunk. Ma már jól látható, hogy 2013. január 23-a nemcsak az Egyesült Királyság, hanem az európai integráció történetébe is sorsfordító napként fog bevonulni. ${ }^{1}$ Ekkor tartotta David Cameron a Bloomberg-beszédét, ${ }^{2}$ amelyben elemezte

${ }^{1}$ Delcker [2016]. Nem tagadva, hogy a brit kilépésnek lényegesen mélyebb és történetileg távolabbra visszanyúló háttere van, lásd ehhez: Somai-Biedermann [2016], O'Rourke [2019].

${ }^{2}$ Lásd: EU speech at Bloomberg. Prime Minister David Cameron discussed the future of the European Union at Bloomberg. (23 January 2013) https://www.gov.uk/government/speeches/eu-speech-at-bloomberg. 
azokat a kihívásokat, amelyekkel az Európai Unió, valamint maga az Egyesült Királyság uniós tagállamként szembesült, és politikájának fő célkitüzéseként az EU brit érdekek alapján történő reformját jelölte meg. A beszéd leglényegesebb üzenete azonban az volt, hogy az „európai kérdést” be kell emelni a brit belpolitikába, és a népnek lehetôséget kell adni, hogy véleményt nyilváníthasson Nagy-Britannia uniós tagságáról. ${ }^{3}$ Ennek megfelelően Cameron kifejezett ígéretet tett arra, hogy népszavazást fog kiírni ebben a tárgykörben, amennyiben a soron következö, 2015-ben esedékes általános választásokon a konzervatív párt kap ismét felhatalmazást kormányalakításra. Cameron ígéretét taktikai célok vezették, így a brit tagság tematizálása mindenekelőtt lehetőséget adott volna arra, hogy a konzervatív párt „kifogja a szelet” az euroszkeptikus Egyesült Királyság Függetlenségi Pártjának (UKIP) vitorlájából. Nigel Farage populista, nacionalista retorikát követő pártja növekvő népszerüségnek örvendett, és új támogatóinak jelentős része a konzervatív párt kiábrándult szavazóiból került ki. Az uniós tagság témájával tehát Cameron elöremenekült, abban bízva, hogy ezzel a konzervatívok pozíciója bebiztosítható lesz a 2015-ös választásokon. Azzal pedig, hogy mindent egy lapra tett fel, nyomás alá helyezte az Európai Uniót is akkor, amikor az általa szükségesnek tartott reformokról tárgyalni kezdett. Lényeges továbbá, hogy habár Cameron Bloomberg-beszédében az Európai Unióval szemben éles kritikát fogalmazott meg, a következtetése inkább optimista volt, és arra utalt, hogy a szükséges reformok az Egyesült Királyság érdekeit és az EU sikerét szolgálják majd. Vagyis feltételezhető, hogy akkoriban Cameron még abban bízott, hogy ha képes lesz az uniós tagállamokkal az általa szükséges reformokról, valamint a britek számára kedvezőbb tagsági feltételekről megállapodnia, az a beígért népszavazáson a bennmaradás mellé sorakoztatja majd fel a szavazókat. ${ }^{4}$

Ma már tudjuk azonban, hogy az előző számítások közül csak az első, a parlamenti választásokkal kapcsolatos várakozások igazolódtak be, de ezek is csak részben. A 2015-ös általános választásokon a konzervatívok ugyan az előző ciklushoz képest növelni tudták képviselőik számát, azonban a UKIP is tovább erősödött, és elöször juttathatott be képviselőket a brit parlamentbe. Az uniós reformok keresztülvitelével kapcsolatos várakozások azonban utólag már alaptalannak bizonyultak.

\footnotetext{
${ }^{3}$ Uo. Lásd még: David Cameron promises in/out referendum on EU. (23 January 2013), BBC News, elérhető: https://www.bbc.com/news/uk-politics-21148282.

${ }^{4}$ Bóka-Halmai-Koller [2016], 59. és köv. o. Mindez nem változtat azon, hogy Cameron ezzel a „kamikaze” lépéssel pártpolitikai célokat helyezett előtérbe, és kikerülte a nehezebb utat, hogy választ kínáljon a háttérben meghúzódó problémákra, vö.: Bujard [2016], 600. o. Mindemellett vitatott is, hogy az ezt követően Cameron által fö társadalmi problémaként a brexitről folyó diskurzusba behozott motívum, az EU-ból érkező bevándorlás valójában nem érintette olyan súlyosan az Egyesült Királyságot, mint amennyire azt hangsúlyozták, lásd ehhez: Czina [2016].
} 
Cameron a népszavazást megelöző időszakban próbálta az Európai Tanács elnökét, valamint a tagállamok vezetőit rábírni a reformok szükségességére, azonban a felvázolt elképzelések az integráció müködésének alapsajátosságait érintették és az integrációs szervezet gyökeres átalakítását igényelték volna. Cameron voltaképpen egy flexibilis és differenciált együttmüködésre épülő, laza Európai Unióban gondolkodott, ami igazából tárgyalási alapnak is nehezen volt elfogadható a tagállamok részéről. Az ennek eredményeképpen 2016 februárjában az Európai Tanácsban elért megállapodást ugyan Cameron próbálta sikerként kommunikálni, arra utalva, hogy a tagállamok a briteknek speciális státuszt biztosítanának az EU-n belül, ${ }^{5}$ a megállapodás részleteit áttekintve felismerhető volt, hogy az csak kihangsúlyozta, egyértelművé tette a britek számára az Európai Unión belül egyébként is meglévő mozgástér egyes részleteit. Következésképpen az elért eredmények inkább retorikai jelentőségűek voltak, és nem tettek mást, mint megerősítették a brit tagsággal kapcsolatban a status quót. ${ }^{6}$ E taktikai megfontolás kudarca mellett pedig a harmadik, leglényegesebb kalkuláció is hibásnak bizonyult. Mint közismert, a 2016. június 23án megtartott és magas részvétel mellett $(72,2 \%)$ zajló népszavazás közismert eredménye alapján ugyanis a szavazók $48,1 \%$-a voksolt a bent maradás, míg 51,9\%-a a kilépés mellett.?

\section{A kilépési folyamat és a kilépési megállapodás}

Az Egyesült Királyság kilépése, vagyis hogy egy tagállam elhagyná az Európai Uniót, az integrációtörténetben eleddig példa nélküli folyamatnak tekinthető, ${ }^{8}$

${ }^{5}$ EU deal gives UK special status, says David Cameron. (20 February 2016), BBC News, elérhetó: https://www.bbc.com/news/uk-politics-35616768.

${ }^{6}$ Lásd: European Council conclusions (18-19 February 2016), elérhető: https://www.consilium.europa.eu/media/21787/0216-euco-conclusions.pdf. A kompromisszum egyedüli lényeges eleme, amely speciális jogokat biztosított, az uniós polgárok bevándorlását érintő korlátozás volt. E szerint az Egyesült Királyság csökkentheti az EU-ból érkező munkavállalóknak nyújtott transzfereket hét éven keresztül, ezt a döntését indokolnia kell és annak életbe léptetéséhez a Tanács hozzájárulására lett volna szükség.

7 Eredményekhez lásd: EU referendum results, elérhető: http://www.bbc.com/news/politics/eu_ referendum/results. Lásd továbbá: Swales [2016].

${ }^{8}$ Az irodalomban gyakran hivatkozott és a brexithez hasonlított események, így pl. Algéria elszakadása Franciaországtól 1962-ben, Grönland státuszának megváltoztatása 1984-ben, vagy a francia tengerentúli területekben történt változás 2007-ben sem nemzetközi jogilag, sem az uniós jog szempontjából nézve nem tekinthetők kilépésnek. Ezek a példák inkább az alapító szerződések és magának az uniós jog területi hatályának megváltoztatását illusztrálják. Erre a jelenlegi alapszerződési keretek 
amelynek explicit jogalapját a lisszaboni szerződés teremtette meg. ${ }^{9}$ Az EUSz 50. cikke értelmében bármely tagállam dönthet úgy, hogy saját alkotmányos követelményeinek megfelelően a kilépés mellett határoz, és e szándékát jeleznie kell az Európai Tanács felé. ${ }^{10}$ A kilépő tagállam és az EU között megindult tárgyalások célja, hogy a felek megállapodjanak a kilépés feltételeiről, amelyet mindkét félnek ratifikálnia kell. A megállapodást az Európai Unió részéről a Tanács minősített többséggel kötheti meg, miután arra az Európai Parlament - a szavazatok többségével jóváhagyását adta. ${ }^{11}$ A kilépési megállapodás tehát jogtechnikai szempontból nézve az Európai Unió által kötött szerződésnek minősül, és az alapszerződés megfelelően alkalmazandó, beleértve a tárgyalásra vonatkozó szabályokat is. ${ }^{12} \mathrm{~A}$ tagság megszünésének lényeges következménye, hogy a tagságból fakadó kötelezettségek teljesítése, jogok érvényesítése megszünik a tagállam vonatkozásában a kilépési megállapodás jogerőre emelkedésének napján, azonban a kilépés időpontjával kapcsolatban az EUSz egy „guillotine-szabályt” is tartalmaz. E szerint megállapodás hiányában a tagság megszűnik a kilépés bejelentésétől számított két év elteltével, hacsak az Európai Tanács egyhangúlag, a többi tagállam beleegyezésével nem dönt úgy, hogy meghosszabbítja a kitűzött határidőt. A kilépés hatásait tekintve végül megemlíthető, hogy habár Cameron Bloomberg-beszédében a kilépést „egy útra szóló jegy” megváltásához hasonlította, ${ }^{13} \mathrm{ez}$ az uniós jog szempontjából nem állja meg a helyét: az EU-t elhagyó tagállamnak ugyanis bármikor lehetősége van a jövőben, hogy újból kérje felvételét a szervezetbe az EUSz 49. cikke szerint.

Ha az említett alapszerződési kereteket behelyezzük a brit kilépési folyamat eseménysorába, akkor a következő fontosabb csomópontok emelhetők ki. Theresa May 2017. március 29-én jelezte hivatalosan az Európai Tanács felé az Egyesült Királyság kilépési szándékát, majd ezt követően a tárgyalás tényleges megkezdésére 2017.

között is viszonylag rugalmasan van lehetőség, sőt ma már a területi hatály megváltoztatása az alapszerződés egyszerüsített eljárásban történő módosítását igényli csak, lásd: EUMSz 355. cikk.

9 A jogalaphoz lásd: Blutman [2016]; Bóka-Halmai-Koller [2016], Gordon-Moffatt [2016], Miller [2016], Osztovits [2011], Prieger-Klemm [2019], valamint: UK withdrawal from the European Union - Legal and procedural issues. European Parliament (March 2017). 4-5. o.

${ }^{10}$ Az Európai Bíróság Wightman-ügyben meghozott döntése alapján azonban a kérelem a kilépési folyamat során egyoldalúan is visszavonható, lásd: Ferencz [2019].

${ }^{11}$ Lásd: Blutman [2016].

12 EUMSz 218. cikke alapján a Bizottság (kül- és biztonságpolitikai tárgyú szerződésnél a külügyi és biztonságpolitikai föképviselö) ajánlásokat nyújt be a Tanácsnak, amely a tárgyalások megkezdéséröl határozatot fogad el. Ebben a határozatban a Tanács kijelöli - a tervezett megállapodás tárgyától függően - az Európai Unió fötárgyalóját vagy tárgyalóküldöttségének vezetőjét.

${ }_{13}$ „If we left the European Union, it would be a 1-way ticket, not a return.” EU speech at Bloomberg. Prime Minister David Cameron discussed the future of the European Union at Bloomberg. (23 January 2013), elérhető: https://www.gov.uk/government/speeches/eu-speech-at-bloomberg. 
június 9-én került sor Brüsszelben. Anélkül, hogy a tárgyalások részletes elemzését adnánk, kiemelhetők a tárgyalások során felmerülő lényeges vitakérdések. ${ }^{14} \mathrm{Az}$ első szakasz egyik fontos témája volt az Egyesült Királyság kilépésének pénzügyi költsége. Az Egyesült Királyság elismerte, hogy fennállhatnak pénzügyi kötelezettségei az EU felé, ${ }^{15}$ amelyek akár a kilépést követő évekre is átnyúlhatnak, azonban e terhek számszerüsítése során már kezdetben lényegesen eltértek a tárgyaló felek elképzelései. Szintén kulcskérdésként jelent meg már a tárgyalások korai szakaszában az uniós és brit állampolgárok jogainak védelme a kilépést követően, valamint törésvonalként jelentkezett a tárgyalásokon az Európai Bíróság jövőbeni szerepének megítélése. Theresa May kezdettől fogva elutasította az EU igényét arra vonatkozóan, hogy az Európai Bíróság a kilépést követően is rendelkezhessen joghatósággal, illetve a Bíróság korábbi esetjogi gyakorlatában kidolgozott jogelveknek továbbra is legyen hatása az Egyesült Királyságban. ${ }^{16}$

A kereskedelmi viszonyrendszer rendezése azonban csak a tárgyalások későbbi szakaszában, 2017 októberében merült fel elöször, ${ }^{17}$ egyből nyilvánvalóvá téve a felek közötti lényeges nézeteltéréseket, megközelítésbeli különbségeket. Az Európai Unió álláspontja szerint a jövőbeni szabadkereskedelmi rendelkezésekről csak a későbbiekben, a kilépési megállapodás főbb kereteinek, az átmeneti időszak feltételrendszerének kialakítását követően tárgyalnának. Ebben a tekintetben az EU pragmatikus álláspontja azt sugallta, hogy a szabadkereskedelmi viszonyról kötendő jövőbeni megállapodás tárgyalása során az Egyesült Királyság helyzete nem lesz kivételes, végső soron hasonló megítélés alá esik majd, mint más harmadik országok, amelyek kereskedelmi megállapodást kívánnak kötni az Európai Unióval. A brit fél ezzel szemben szorgalmazta, hogy a tárgyalásokat terjesszék ki a jövőbeni kereskedelmi viszonyrendszer feltételeire is. A brit főtárgyaló, David Davies egyenesen úgy fogalmazott, hogy amennyiben a tárgyalások ezen szakaszában nem lesznek ismertek a tartós kereskedelmi viszonyrendszer keretei, az mindenképpen további bizonytalanságot fog okozni, és így ehhez képest még egy megállapodás nélküli, „,no deal” brexit is kedvezőbb lenne az Egyesült Királyság számára. ${ }^{18}$

Lényeges továbbá, hogy ebben az időszakban még az Egyesült Királyság sem rendelkezett határozott pozícióval abban a tekintetben, hogy milyen modell alapján

${ }^{14}$ Részletesen lásd: Forgács [2018].

15 Akár tartósan is, pl. a brit „eurokraták” későbbi nyugdíjának finanszírozása kapcsán, amelynek fedezetét jelenleg az uniós költségvetés biztosítja.

16 Lásd: Rawlinson [2017], Watts [2017].

${ }^{17}$ Lásd: Miller-Lang-Mcguinness-Keep-Curtis [2017], 12-13. o.

${ }^{18}$ Lásd: Asthana [2017]. 
alakítsák majd ki a kereskedelmi feltételeket. A szóba jöhető modellekről - EGTmodell, svájci modell, vámunió, szabadkereskedelmi modell stb. - javában folyt a vita még akadémiai körökben is. ${ }^{19}$ Az ezzel kapcsolatos brit vízió hiánya azért is volt különösen problematikus, mert az egyes forgatókönyvek lényegileg különböző pénzügyi-gazdasági következményeket valószínúsítettek, valamint a különböző modellek a szuverenitási megfontolásokat, így a népszavazási kampányüzenetének (,,Taking back control”) gyakorlati következményeit is behatárolták. Végül a brit a kormány 2018 nyarán állt elő a sajtóban csak „,Chequers Plan”-ként hivatkozott fehér könyvvel, ${ }^{20}$ amely vámjogi megállapodást (,,Facilitated Customs Arrangement”), és a termékforgalom jelentős részére kiterjedő közös szabályokat irányzott volna elő. E szerint az EU és az Egyesült Királyság között nem alkalmaztak volna vámeljárásokat a késztermékek vonatkozásában, a termékek (ipari, mezőgazdasági és halászati termékek) nagy részében pedig eltörölték volna a vámokat és a mennyiségi korlátozásokat. A tervezetből kuriózumként említhető az a sajtos kumulációs szabály, amely a két fél által kötött szabadkereskedelmi megállapodások egyes előnyeit kapcsolta volna össze, nevezetesen az EU és az Egyesült Királyság termékei belföldi státuszú terméknek minősültek volna a másik fél szerződései vonatkozásában. Az EU főtárgyalója azonban nem támogatta ezt a javaslatot, ${ }^{21}$ így ebben a formájában nem került a tárgyalók asztalára.

De nemcsak a hosszú távú kapcsolatokról, hanem az átmeneti időszak szabályairól sem tudtak a felek egykönnyen megegyezni, egészen 2018. október végéig úgy tünt, hogy a tárgyalásokat nem sikerül a feleknek kizökkenteniük a holtpontról. Végül 2018. november 14-én kötöttek kompromisszumot a kilépési megállapodás szövegéről. A felek a megállapodás mellett egy nem kötelező politikai nyilatkozatot is elfogadtak, amely a jövőbeni kapcsolatok föbb elveit foglalta össze. A kilépési megállapodás Achilles-sarka azÍrország és Észak-Írország státuszát szabályozó jegyzőkönyv és az abban bevezetni kívánt megoldás (,,backstop”) volt. Ennek elsőd-

${ }^{19}$ Lásd a hazai és külföldi irodalomból pl.: Bóka-Halmai-Koller [2016], Cabral-GonçalvesRodrigues [2017], Emerson [2016], Tomlinson-Boyes [2017], Török [2017].

${ }^{20}$ White Paper on the future relationship between the United Kingdom and the European Union presented to Parliament by the Prime Minister by Command of Her Majesty (July 2018), elérhető: https:// assets.publishing.service.gov.uk/government/uploads/system/uploads/attachment_data/file/786626/ The_Future_Relationship_between_the_United_Kingdom_and_the_European_Union_120319. pdf. (A dokumentum a "Chequers” elnevezést a brit miniszterelnök Ellesborough közelében fekvő Chequers Court palotája után kapta. Itt tartották azt a kormányülést, amelyen a fehér könyvet elfogadták.)

${ }^{21}$ The View from Brussels. (July 2018), Herbert, Smith, Freehills, elérhetö: https://www.herbertsmithfreehills.com/latest-thinking/brexit-the-view-from-brussels- $\%$ E2 $\% 80 \% 93$-developments-in-july. 
leges célja, hogy a kilépés folyamatában elkerülhető legyen a határellenőrzés újbóli bevezetése az ír szigeten, vagyis hogy továbbra fennmaradjon Írország és ÉszakÍrország között a szabad mozgás lehetősége. Mindez az északír béke szempontjából nemcsak politikailag, hanem az 1998-ban elfogadott nagypénteki egyezmény ${ }^{22}$ alapján jogilag is lényeges kérdés volt. Az eredeti jegyzőkönyv szerint az átmeneti időszakot követően az Egyesült Királyság továbbra is a vámunió része maradt volna mindaddig, amíg a jövőbeni kapcsolatokról szóló egyezményről a felek nem tudtak volna megállapodni. Ezáltal Írország és Észak-Írország viszonyában határellenőrzésre sem lett volna szükség ezen időszak alatt, viszont fennállt a rizikója annak, hogy ha nem sikerülne a jövőbeni kapcsolatokat rendezni egy végleges szerződésben, akkor a britek ,bent ragadhattak” volna a vámunióban. Nem mellesleg mindez a britek számára harmadik államokkal szemben is kedvezőtlenebb helyzetet teremtett volna, ugyanis a vámunióban fennmaradó tagságuk és a jövőbeni, végleges szerződéssel kapcsolatos bizonytalanságok nagyban nehezítették volna, hogy harmadik államokkal szabadkereskedelmi egyezményeket kössenek. Ennek is betudható, hogy végül a tervezett 2019. tavaszi kilépési dátumig Theresa Maynek háromszori próbálkozásra sem sikerült a kilépési megállapodást elfogadtatnia a londoni parlamenttel. Elkerülendő a megállapodás nélküli hard brexitet, az Egyesült Királyság a kilépés elhalasztását kezdeményezte, minek eredményeképpen végül a felek 2019. október 31-ig hosszabbították meg a kilépés dátumát.

A kilépési megállapodás parlamenti elfogadásával kapcsolatos kudarc is hozzájárult ahhoz, hogy Theresa May lemondott és helyét 2019. július 23-ától Boris Johnson foglalhatta el. Johnson programja szerint az Egyesült Királyságot „,mindenáron" ki akarta vezetni október 31-ig az Európai Unióból, vállalva akár a hard brexit következményeit is. Ösz elejétől kezdődően voltaképpen Boris Johnson már nyíltan erre a lehetőségre is játszott: felfüggesztette a parlamentet, amelyet azonban a brit legfelsőbb bíróság (Supreme Court) jogellenesnek mondott ki. ${ }^{23}$ A tárgyalások a kilépési feltételek módosításáról az EU-val tovább folytak, amelynek eredményeképpen sikerült a feleknek megegyezniük 2019. október 17-én. A módosított megállapodás elfogadása a brit parlament részéről már nem volt kivitelezhető a tervezett október végi kilépési dátumig, így az ún. Benn Act értelmében az Egyesült Királyság újabb halasztást kezdeményezett, amit 2020. január 31-ig meg is kapott. ${ }^{24}$ Jelenleg - figye-

${ }^{22}$ Northern Ireland Peace Agreement (The Good Friday Agreement, 10/04/1998), elérhető: https:// peacemaker.un.org/uk-ireland-good-friday 98 .

${ }^{23}$ Lásd: Bowcott [2019].

${ }^{24}$ Hogy Johnson mennyire számolt a hard brexittel, jól mutatja, hogy 2019. október 19-én, amikor a Benn Act alapján újabb hosszabbítást kellett kérnie, két levelet küldött az Európai Tanács elnökének. 
lembe véve a 2019. december 12-i általános választás eredményeit és a bevezetőben írtakat - a legvalószínűbb, hogy az új brit parlament jóvá fogja hagyni az idén ősszel módosított megállapodást, és az Egyesült Királyság kilépése legkésőbb 2020. január végéig meg fog történni. ${ }^{25} \mathrm{~A}$ következőkben a kilépési megállapodást mutatjuk be, annak is elsősorban a kereskedelmi kapcsolatokat érintő szabályait vizsgáljuk.

\section{A kilépési megállapodá $\mathrm{s}^{26}$ kereskedelmi rendelkezései}

\subsection{A megállapodás általános jellemzése}

Az elmondottak alapján is látható, hogy a kilépési megállapodás csak az Egyesült Királyság kilépésének azonnal jelentkező, fontosabb aspektusait szabályozza, de nem rendelkezik a hosszú távú, jövőbeni EU-brit kapcsolatokról. ${ }^{27}$ Ennek föbb kérdéseit a felek által elfogadott politikai nyilatkozat tartalmazza, ${ }^{28}$ amelyet a 2019. októberi módosítás szintén érintett. A felek közötti jövőbeni kapcsolatok kialakítása - beleértve a kereskedelmi kapcsolatrendszer elveit - további tárgyalásokat igényel

Az elsőben hivatalosan eleget tett előző kötelezettségének, a másikban viszont voltaképpen arról kívánta meggyőzni a tagállamokat, hogy a kilépés újbóli elhalasztása rendkívül káros lenne az Egyesült Királyságra nézve. A hosszabbítás elmaradása ekkor hard brexit bekövetkeztét jelentette volna október végével. Johnson levelei elérhetők: Boris Johnson's Brexit delay letters in full, BBC News (20 October 2019), elérhető: https://www.bbc.com/news/uk-50114538.

25 A kilépési dátum meghosszabbításával kapcsolatos kompromisszum alapján az Egyesült Királyságnak lehetősége van kilépni 2020. január 31-ét megelözően is, jelesül annak a hónapnak a végével, amikor a parlament a kilépési megállapodást jóváhagyja. Elméletileg ez alapján jelen sorok megfogalmazásakor nem zárható ki, hogy a londoni parlament még decemberben megadja a hozzájárulását, így 2019. december 31-én megtörténhetne a kilépés, azonban jelenleg inkább reálisabbnak tủnik egy „nyugodtabb tempójú” parlamenti eljárás, aminek eredményeképpen január végén hagynák el a britek az Európai Uniót.

${ }_{26}$ Megállapodás a Nagy-Britannia és Észak-Írország Egyesült Királyságának az Európai Unióból és az Európai Atomenergia-közösségből történő kilépéséről. HL „C” 384 (2019.11.12.). A továbbiakban: Megállapodás.

${ }^{27}$ Ez alól kivételt képez az ír és északír viszonyt rendező jegyzökönyv, amely hosszabb távú rendelkezéseket is tartalmaz, lásd a e cikk 4.3 alfejezetét.

${ }^{28}$ Politikai nyilatkozat az Európai Unió és az Egyesült Királyság közötti jövőbeli kapcsolatok keretének meghatározásáról, HL „C” 66 (2019.2.19.). A 2019 októberében módosított szöveg jelenleg magyarul nem elérhető, lásd: Revised political declaration setting out the framework for the future relationship between the European Union and the United Kingdom, elérhető: https://ec.europa.eu/ commission/publications/revised-political-declaration_en. A módosított dokumentum a továbbiakban: Nyilatkozat. 
majd, amelyre a kilépést követően fog sor kerülni és várhatóan a kilépés utáni átmeneti időszak végéig, 2020. december 31-ig lezárhatók lesznek e tárgyalások. ${ }^{29}$

A megállapodás az általános rendelkezéseket követően (Első rész: Közös rendelkezések) az uniós polgárok helyzetét rendezi az átmeneti időszakban (Második rész: A polgárok jogai). A megállapodás harmadik szakasza tartalmazza a kilépés részletes feltételrendszerét meghatározó szabályokat (Harmadik rész: A kilépéssel kapcsolatos rendelkezések), a negyedik szakasz az átmeneti időszak szabályait foglalja magába (Negyedik rész: Átmenet), az ötödik a kilépés pénzügyi feltételeit (Ötödik rész: Pénzügyi rendelkezések), valamint a hatodik záró, vegyes szabályokat (Hatodik rész: Intézményi és záró rendelkezések) tartalmazza. A megállapodás külön jegyzőkönyvben rendezi Észak-Írország, Ciprus és Gibraltár viszonyát az Európai Unióval. ${ }^{30}$

A megállapodás jogi szempontból nézve az Egyesült Királyságnak az Európai Unióból, valamint az Európai Atomenergia-közösségből (Euratom) mint jogi személyiséggel felruházott nemzetközi szervezetekből történő kilépését szabályozza. ${ }^{31}$ Lényeges viszont, hogy a kilépés ellenére a megállapodással érintett uniós jog, amelyet a felek az átmeneti időszak alatt is kötelezőnek tekintenek, ugyanolyan módon fejti ki hatását, mint a tagállamokban, példának okáért közvetlen hatállyal bíró normák esetében jogi vagy természetes személyek közvetlenül hivatkozhatnak a vonatkozó rendelkezésekre. ${ }^{32}$ Fontos továbbá, hogy a lojális együttmüködés elvét a felek kifejezetten kiterjesztik a megállapodásra is az alapszerződési megfogalmazással azonos módon. ${ }^{33} \mathrm{Az}$ átmeneti időszakban az Európai Bíróság joghatósága is fennmarad, tehát a Bíróság ítéletei és végzései teljes egészében kötelező erővel bírnak majd az Egyesült Királyságban. ${ }^{34}$

${ }^{29}$ Megállapodás 126. cikk. Lehetőség van azonban majd az átmeneti időszak meghosszabbítására egy vagy két évvel, lásd: Megállapodás 132. cikk.

30 Jegyzőkönyv Írországról/Észak-Írországról; Jegyzőkönyv Nagy-Britannia és Észak-Írország Egyesült Királyságának Ciprusi Felségterületeiről; Jegyzőkönyv Gibraltárról.

31 Lásd: Megállapodás 1. cikk.

32 Vö. Megállapodás 4. cikk.

${ }^{33}$ Lásd: Megállapodás 5. cikk. Ez alapján az EU és az Egyesült Királyság „,[...] kölcsönösen tiszteletben tartja és jóhiszemüen segíti egymást az e megállapodásból fakadó feladatok végrehajtása során. Az Európai Unió és az Egyesült Királyság minden megfelelő - általános vagy különös - intézkedést meghoz az e megállapodásból fakadó kötelezettségek teljesítésének biztosítása érdekében, és tartózkodik minden olyan intézkedéstől, amely veszélyeztetheti e megállapodás célkitűzéseinek megvalósítását."

34 Lásd: Megállapodás 89. cikk. 


\subsection{Az átmeneti idöszak alatti kereskedelmi rendelkezések}

Amennyiben a brit parlament elfogadja a kilépési megállapodást, az átmeneti időszak alatt az EU és az Egyesült Királyság közötti kereskedelmi viszonyrendszerben nagyon látványos változások egyelőre még nem fognak bekövetkezni. Habár formailag az Egyesült Királyság önálló vámterületet fog képezni, az árukereskedelem vonatkozásában jórészt továbbra is alkalmazandó lesz az uniós belső piaci jog. Ennélfogva az EU-brit együttmüködést az átmeneti időszakban egy olyan kereskedelmi együttműködésként írhatjuk le, amelyben ugyan párhuzamosan két vámterület létezik, azonban az egymás közötti kereskedelemben azonos szabályokat alkalmaznak. A párhuzamos vámjogi rendszerek müködtetése nem számít példa nélkülinek a nemzetközi kereskedelmi jog történetében, illetve jelen gyakorlatban is találunk hasonló megoldásokat. ${ }^{35} \mathrm{~A}$ kilépési megállapodás különlegessége azonban abban rejlik, hogy a közös - azonos - vámjogi szabályokat a felek nem jogegységesítés vagy harmonizáció útján érik el, hanem az immáron szuverén állam, Nagy-Britannia a megállapodásban vállal kötelezettséget egy a perspektívájából nézve külsőnek tekinthető rezsim alkalmazására. Ennélfogva a vonatkozó uniós jogot a brit jogalkalmazónak, beleértve a brit bíróságokat is azonos módon kell majd érvényre juttatniuk az átmeneti időszakban is, mint arra még jelenleg az uniós tagságból fakadóan kötelesek.

Az alapszerződés logikájához képest az áruk szabad áramlásának garanciáit a megállapodás részben eltérő módon biztosítja. Mivel két vámterületről van szó, így a megállapodás nem a vámokat érintő rendelkezésekről, hanem csak általánosságban az „áruk folyamatos szabad mozgásáról” szól. Ez alapján az átmeneti időszak végéig az EU-ban, illetve az Egyesült Királyságban jogszerüen forgalomba hozott áru az uniós, illetve brit piacon tovább forgalmazható, a végfelhasználóig eljuttatható, valamint használatba vehetô. ${ }^{36} \mathrm{~A}$ gyakorlatban is jelentkező változás, hogy áruk vámjogi státuszát minden esetben igazolni szükséges (praktikusan fuvarokmánnyal). ${ }^{37}$

35 Történeti példák alapján Franciaországban az Ancien régime időszakában működött osztott vámrendszer, amelyet II. János vezetett be 1360-ban, de párhuzamos vámjogi rezsim működött az osztrák birodalomban is Mária Terézia ideje alatt, amikor Magyarország nem volt része az osztrák vámuniónak, hanem önálló vámterületnek minősült. Mai példák közül említhetjük a Latin-Amerikai Integrációs Társulás megoldását, amelyben a részt vevő államok fejlettségét figyelembe véve Bolívia számára kedvezőbb vámszabályokat alkalmaznak. Lásd: Pardavi [2015], 31., 41. és 144. o.

36 Lásd: Megállapodás 41. cikk.

37 Lásd: Megállapodás 47. cikk. 
Következésképpen az uniós vámjog vélelemre épülő föszabálya ${ }^{38}$ azaz hogy az EU vámterületén az áruk uniós vámjogi státusszal rendelkező áruknak tekintendők mindaddig, amíg nem nyer megállapítást ennek ellenkezője, nem alkalmazandó. Ezen túlmenően fontos lehet annak igazolása is, hogy az adott terméket még az átmeneti időszak végét megelőzően bocsátották szabad forgalomba: ennek tényét az érintett gazdasági szereplő bármilyen releváns dokumentum alapján tudja bizonyítani. $^{39}$

A kilépési megállapodással a két piac (vámterület) között a mennyiségi korlátozások és az azzal azonos hatású intézkedések alkalmazása is tilalmazott lesz az áruk szabad áramlásának uniós jogi garanciáihoz hasonlóan. A megállapodás ebben a tekintetben kifejezetten utal az EUMSz 34-35. cikkeire, valamint arra, hogy e korlátozásokra a vonatkozó „uniós jogban foglalt” követelmények irányadóak. Előző fogalmat maga a megállapodás is meghatározza, az alapján az „uniós jog” alatt az Európai Bíróság által kidolgozott általános elvek is értendők. ${ }^{40}$ Következésképpen e rendelkezés alapján a mennyiségi korlátozásokkal azonos hatású intézkedésekre vonatkozó jogelvek - kölcsönös elismerés elve, kényszerítő követelmények, Keckformula stb. - is alkalmazandó lesz az átmeneti időszakban. ${ }^{41}$ Lényeges különbség ellenben az uniós alapszerződési keretekhez képest, hogy a megállapodás csak az áruforgalommal összefüggő adók (áfa, jövedéki adó stb.) kapcsán utal az alkalmazandó uniós forrásokra, viszont nem tartalmaz az EUMSz 114. cikkéhez hasonló, átfogó garanciát a hátrányosan megkülönböztető adókkal szemben. Ezen túlmenően tárgyi kivételeket is meghatároz a megállapodás, amelyekre nem lesznek alkalmazandók az áruk szabad mozgásának szabályai, ${ }^{42}$ illetve egyes termékcsoportok kapcsán további részletszabályokat is megfogalmaz. ${ }^{43}$

38 Lásd: Európai Parlament és Tanács 952/2013/EU rendelete (2013. október 9.) az Uniós Vámkódex létrehozásáról 153. cikk (1) bekezdés.

39 Lásd: Megállapodás 42. cikk.

40 Lásd: Megállapodás 2. cikk (a) pont.

${ }^{41}$ Megjegyezhető azonban, hogy a megállapodás a Keck-formula által érintett értékesítési feltételek vonatkozásában némileg értelemzavaró rendelkezést is tartalmaz. A hivatkozott, mennyiségi korlátozásokról szóló különálló norma ugyanis arra utal, hogy az nem érinti többek között az értékesítés módjára vonatkozó szabályokat (,E cím rendelkezései nem érintik az értékesítés módjára, a szellemi tulajdonra, a vámeljárásokra, a díjakra és adókra vonatkozó szabályokat.”), Megállapodás 6. cikk. E szabály rendszertani értelmezése alapján nem ezen elemek korlátozására vonatkozik, hanem éppen ellenkezőleg, hogy ezek alkalmazása - tehát az értékesítési módokat érintő uniós követelmények figyelembevétele - kötelező.

${ }^{42}$ Lásd: Megállapodás 41. cikk (3). Kivételként nevesíti élő állatokat és szaporítóanyagokat és állati termékeket.

${ }^{43}$ Gyógyszerek, szellemi tulajdonjogok, adózás, vámeljárások stb. vonatkozásában. 


\subsection{Speciális kereskedelmi szabályok az Észak-Írországot érintő áruforgalomban}

Az előzőekben szó esett arról, hogy a kilépési megállapodás eredeti, 2018-as változatában az „északír kérdést” rendező jegyzőkönyv váltotta ki a legtöbb vitát. Ennek oka elsősorban, hogy a jegyzőkönyv olyan problémakomplexumot kíván kezelni, amely együttesen nehezen megvalósítható célok összehangolását igényelné. Az uniós és brit fél, valamint az ír és az északír közösségek érdekeit is alapul véve a jegyzőkönyvnek egyszerre kellene megfelelnie a már hivatkozott nagypénteki megállapodásnak, ${ }^{44}$ meg kellene akadályoznia, hogy tényleges vámhatár szelje ketté az ír szigetet, így szavatolni kellene, hogy gazdaságilag egységes maradjon a sziget, mindeközben olyan megoldást kellene találni, amely nem sérti az uniós belső piac integritását és a különváló brit vámterület érdekeit sem.

A jegyzőkönyv 2019 őszén elfogadott módosítása ${ }^{45}$ kísérletet tesz e célok összeegyeztetésére. Vámjogilag Észak-Írországot az Egyesült Királyságon belül tartja, ${ }^{46}$ azonban az északír terület vonatkozásában az uniós belső piaci szabályok egy része továbbra is alkalmazásra kerül annak érdekében, hogy a forgalom e terület és Írország között az átmeneti időszakban zavartalan maradjon. E kompromisszumos megoldás lehetővé teszi, hogy az Egyesült Királyság már az átmeneti időszak alatt szabadkereskedelmi megállapodásokat tárgyaljon le és kössön meg harmadik államokkal, amelyek az Észak-Írországban elóállított termékeket ugyanolyan elbánásban részesíthetik majd, mint az Egyesült Királyság bármely más részén előállított termékeket. Nemzetközi kereskedelmi jogi szempontból szintén lényeges, hogy a brit kormány által a Kereskedelmi Világszervezetben (WTO) vállalt koncessziós listában Észak-Írország tekintetében is rendelkezhet kötelezettségről, ennek ugyanis előfeltétele, hogy azonos vámterületről legyen szó. ${ }^{47}$ Észak-Írország „kettős vám-

44 Lásd: Jegyzőkönyv 1. cikk (1): „Ez a jegyzőkönyv nem érinti az 1998. évi megállapodás ÉszakÍrország alkotmányos státuszára vonatkozó rendelkezéseit, valamint a hozzájárulás elvét, amely szerint az ilyen státusszal kapcsolatos bármilyen változás csak az észak-ír lakosság többségének egyetértésével történhet."

45 Megállapodás a Nagy-Britannia és Észak-Írország Egyesült Királyságának az Európai Unióból és az Európai Atomenergia-közösségből történő kilépéséről, Jegyzőkönyv Írországról/Észak-Írországról. Továbbiakban: Jegyzökönyv.

${ }^{46}$ Lásd: Jegyzőkönyv 4. cikk: „Észak-Írország az Egyesült Királyság vámterületének részét képezi $[\ldots]$.

${ }^{47}$ Az Európai Unió mellett az Egyesült Királyság is a WTO alapító tagja, azonban az EU-nak egységesen, az uniós vámterület vonatkozásában kellett koncessziókat vállalnia. Nagy-Britannia kiválásával e helyzet megváltozik, és a feleknek szét kell választaniuk kötelezettségeiket. Ennek eredményeképpen az EU módosítja kedvezményes listáit, a britek pedig önálló koncessziós kötelezettségvállalást fognak tenni. (E folyamat a WTO-n belül már 2017-ben megindult.) 
jogi státusza" leegyszerüsítve akként jelentkezik majd a gyakorlatban, hogy ameddig az áru csak Észak-Írország és Nagy-Britannia további területei között mozog, nem alkalmazzák az uniós vámjogot. Abban az esetben viszont, ha „fennáll annak a kockázata", ${ }^{48}$ hogy az árut a későbbiekben - akár önmagában, akár feldolgozást követően egy másik áru részét képezően - az EU-ba szállítják, ez esetben az uniós vámjogi szabályokat érvényre kell juttatni, vagyis az uniós vámkódex ki fog terjedni ezen árukra Észak-Írország területén. A gyakorlatban ez azt jelenti majd, hogy az Egyesült Királyság más területéről származó árukra - a brit szabályoktól függően vámot fog kivetni az északír hatóság (ellenkező esetben, tehát ha a fenti „kockázat” nem áll fenn, az áru értelemszerüen szabadon mozog majd Észak-Írország és a többi brit terület között).

A vámjogi szabályok mellett a jegyzőkönyv kifejezetten alkalmazni rendeli a mennyiségi korlátozásokkal összefüggő, valamint a diszkriminatív adókra vonatkozó szabályokat, valamint meghatározza azokat a belső piaci normákat, amelyeket ÉszakÍrországban is alkalmazni kell. ${ }^{49}$ Ebben a tekintetben jól látható, hogy az alkalmazandó szabályok révén az északír terület erőteljesen beágyazódik a belső piacba, így a releváns uniós jog nagyon széles terjedelemben - az adójogi rendelkezésektöl egészen a versenyjogi, állami támogatásokkal stb. kapcsolatos követelményekig - érvényesülni fog. ${ }^{50}$ Ebből kifolyólag Észak-Írország státusza önmagában is nemzetközi kereskedelmi jogi kuriózumot jelent majd, hiszen annak ellenére, hogy formailag brit vámterülethez fog kötődni, a termékforgalmának nagyobb részét kitevő, Írországgal folytatott termékek belső piaci elbírálás alá esnek, így voltaképpen gazdaságilag erőteljesen integrálják az ír sziget gazdaságába, ezen keresztül végső soron az uniós gazdaságba.

Észak-Írország speciális helyzete elválik az egyezmény általános rendelkezései kapcsán előírt átmeneti időszaktól. Az északír terület belső piaci integrálása a kétéves átmeneti szakaszt követő négyéves időszakban is fennmaradhat, azonban csak az Észak-írországi Nemzetgyülés hozzájárulása mellett, amely nélkülözhetetlen ahhoz, hogy a nagypénteki megállapodás által megkövetelt demokratikus egyetértés alakuljon ki a terület státusza tekintetében. A jegyzőkönyv lehetőséget ad akár egymást követő újabb négyéves időszakokra történő hosszabbításra is, tehát az észak-írországi törvényhozás hosszabb távra is biztosíthatja majd a terület belső piaci beágyazottságát. ${ }^{51}$

${ }^{48}$ Lásd: Jegyzökönyv 5. cikk.

${ }^{49}$ Lásd: Jegyzőkönyv 5. cikk (4)-(5) bekezdések.

${ }^{50}$ Lásd: Jegyzökönyv 2. melléklet.

${ }^{51}$ Lásd: Jegyzökönyv 18. cikk. 
Az Európai Unió és az Egyesült Királyság kereskedelmi jogi kapcsolatrendszere...

4.4 A jövőbeni kereskedelmi kapcsolatok keretei

Habár a 2019. december 12-i választásokat követően a brexitet övező bizonytalanságok kezdenek eloszlani, így - miként arra utaltunk - ma már inkább valószínűbb, hogy az Egyesült Királyság a kilépési szerződés keretei között, rendezett módon fogja elhagyni az Európai Uniót, nagy valószínüséggel a kilépés utáni időszakot sem csak kizárólag a nyugalom fogja jellemezni. Ezt követően ugyanis a feleknek az átmeneti időszak alatt ki kell dolgozniuk a hosszú távú kereskedelmi kapcsolatrendszer kereteit és ez a brexit-tárgyalásokon már korábban előkerült nézeteltéréseket újból felszínre hozhatja. Következésképpen annak a veszélye, hogy végül hosszú távon a brit-EU kereskedelmet az alapszintủ WTO-szabályok határozzák meg, még továbbra is fennáll. Éppen ezért várhatóan fordulatokban nem lesz kevésbé gazdag a kilépést követő kétéves időszak sem.

A felek jövőbeni kapcsolatokra vonatkozó preferenciáit a kilépési megállapodás mellett elfogadott és 2019 őszén szintén módosított politikai nyilatkozat tartalmazza. Ez alapján a brit kormány jelenleg egy szabadkereskedelmi megállapodás letárgyalását és megkötését tekinti céljának, amely alapvetően vámmentes kereskedelmet biztosítana az EU és az Egyesült Királyság között, és a származási szabályok modern megközelítésére, valamint ambiciózus vámjogi kötelezettségvállalásokra épülne. ${ }^{52} \mathrm{Az}$ árukereskedelmen túlmenően a nemzetközi kereskedelem további területeit (szolgáltatások, töke- és fizetési müveletek stb.) is szabályozni kívánják majd a felek. A deklaráció alapján a felek célja mindenképpen egy átfogó megállapodás megkötése lesz, így nem kizárt, hogy az EU tárgyalási alapként az utóbbi években számos harmadik állammal megkötött ún. újgenerációs szabadkereskedelmi megállapodásokból fog kiindulni. Összegezve tehát, ma már az mindenképpen megkönnyíti az elöretekintést, hogy világosak Nagy-Britannia céljai. Mindez természetesen nem jelent garanciát arra, hogy a feleknek zökkenőmentesen, gyors tárgyalások keretében sikerül majd megállapodniuk, várható, hogy olyan területeken, mint pl. az eredetvédelem és földrajzi árujelzők, vagy a szolgáltatások szabadságának terjedelme, a felek eltérő megközelítései nehezebben lesznek csak összeegyeztethetők.

${ }^{52}$ Lásd: Nyilatkozat B. 22. szakasz. 


\section{Záró megjegyzések}

A brexit tanulságai még hosszú időn keresztül képezik vizsgálatok tárgyát, de az már most bizonyos, hogy hatásai nemcsak az Egyesült Királyságot, hanem az Európai Uniót is érintik majd, és így csak bízni lehet abban, hogy a brit kilépés az integrációtörténet egyedi eseménye marad. ${ }^{53} \mathrm{~A}$ szétválás folyamata a jogi szabályozás szempontjából sem könnyű feladat, és ahogyan elemzésünk bemutatta, akár apró kereskedelmi részletszabályokon is múlhat a megállapodás sorsa.

Mindemellett lényeges az is, hogy a brexit jelenlegi kompromisszuma egyelöre a kilépést követő rövidebb, átmeneti időszak tekintetében teremt tiszta helyzetet. Várhatóan jóval nagyobb tétje lesz a Nagy-Britannia és az EU közötti jövőbeni tartós kereskedelmi viszonyrendszert szabályozó megállapodásnak. A felek közötti alku számos tényezőtől függ majd, de ami már most sejthető: a brit tárgyalási pozíciót nagyban befolyásolja majd, hogy az elkövetkező időszakban mekkora eredményességgel lesz képes harmadik államokkal szabadkereskedelmi egyezményeket kialkudni. A brit kilépést követő időszakban tehát nem csak a két fél közötti tárgyalásoknak lesz jelentőségük, hanem egyfajta „versenyfutás” indulhat az Európai Unió és az Egyesült Királyság között a harmadik államok piacaira vonatkozó minél kedvezőbb szabadkereskedelmi feltételek kialkudásáért. Eljátszva a gondolattal, e versenyben az EU elég jó pozícióból indulhat, számos nagy gazdasággal már sikerült szerződést kötnie (pl. Kanada vagy Japán), így a brit kormány csak kifejezetten ambiciózus eredményekkel lenne képes felvenni a versenyt ebben a tekintetben az Európai Unióval. Feltételezhetően ilyen eredmény lenne adott esetben, ha Nagy-Britanniának sikerülne az Egyesült Államokkal szabadkereskedelmi megállapodást kötnie, vagy ha úgymond „beelőzné” a Kínával már tárgyalásokat folytató Európai Uniót, és a világ második legnagyobb gazdaságához is szabadkereskedelmi egyezménnyel csatornázhatná be a szigetország kereskedelmi kapcsolatrendszerét.

\section{Irodalomjegyzék}

Asthana, Anushka [2017]: Chances of no-deal Brexit have ,dropped dramatically' - David Davis. The Guardian (10 December 2017). Elérhetö: https:/www.theguardian.com/politics/2017/dec/10/nodeal-brexit-odds-dropped-dramatically-david-davis.

Blutman László [2016]: A Brexit a nemzetközi jog látószögéből. Közjogi szemle, 9. évf., 3. sz., 18-25. o.

${ }^{53}$ És nem szolgáltat más tagállamok, így Magyarország kilépésének forgatókönyveként, lásd ehhez Gálik [2019]. 
Bóka János - Halmai Péter - Koller Boglárka [2016]: Válás „,angolosan”. A Brexit politikai, jogi és gazdasági agendái. Pro Publico Bono, 2016/2, 59-61. o.

Bowcott, Owen [2019]: Johnson's suspension of parliament unlawful, supreme court rule. The Guardian (24 September 2019). Elérhető: https://www.theguardian.com/law/2019/sep/24/boris-johnsonssuspension-of-parliament-unlawful-supreme-court-rules-prorogue.

Bujard, Birgit [2016]: Vereinigtes Königreich. In: Weidenfeld, Werner - Wessels, Wolfgang (szerk.): Jahrbuch der Europäischen Integration 2016. Nomos, Baden-Baden. 591-600. o.

Cabral, Nazaré da Costa - Gonçalves, José Renato - Rodrigues, Nuno Cunha [2017]: After Brexit. Consequences for the European Union. Palgrave Macmillan, Cham.

Czina Veronika [2016]: Nem létező probléma a Brexit kampány hátterében? - Andor László volt magyar EU biztos előadása az ELTE-n. JTI Blog (2016. március 22.). Elérhető: https://jog.tk.mta. $\mathrm{hu} / \mathrm{blog} / 2016 / 03 /$ nem-letezo-problema.

Delcker, Janosch [2016]: Angela Merkel: Brexit is „Watershed for Europe”. Politico (24 June 2016), Elérhető: http://www.politico.eu/article/angela-merkelbrexit-is-watershed-for-europe-brexit-eureferendum/.

Emerson, Michael [2016]: Which model for Brexit? CEPS Special Report, No. 147 (October 2016).

Ferencz Barnabás [2019]: Egyoldalúan visszavonható-e az Európai Unióból való kilépésre vonatkozó szándéknyilatkozat? A C-621/18 Wightman és társai ügy ítélete. Európai jog, 19. évf., 1. sz., 38 40. o.

Forgács Imre [2018]: Anarchikus Brexit (A brit kilépés nyitott kérdései a hivatalos dokumentumok alapján. Jogtudományi közlöny, 73. évf., 4. sz., 173-181. o.

Gálik Zoltán [2019]: A brexit tanulságai a huxit számára. Külgazdaság, 63. évf., 5-6. sz., 27-33. o.

Gordon, Richard - Moffatt, Rowena [2016]: Brexit: The immediate legal consequences. The Constitution Society. London, 2016. Elérhetö: https://consoc.org.uk/wp-content/uploads/2016/05/ Brexit-PDF.pdf.

Miller, Vaughne - Lang, Arabella - Mcguinness, Terry - Keep, Matthew - Curtis, John [2017]: Brexit: the September negotiations (6 October 2017). House of Commons Library, London. Elérhetö: https://researchbriefings.parliament.uk/ResearchBriefing/Summary/CBP-8104.

Miller, Vaughne [2016]: EU Referendum: the process of leaving the EU. House of Commons Library (8 April 2016).

O’Rourke, Kevin [2019]: A Short History of Brexit. Penguin, London.

Osztovits András [2011]: Az Európai Unióról és az Európai Unió működéséről szóló szerződések magyarázata. CompLex, Budapest, 2011.

Pardavi László [2015]: A globális gazdaság vámjogának alapkérdései különös tekintettel a preferenciális szerződésekre. Universitas-Györ Nonprofit Kft, Győr.

Prieger Adrienn - Klemm Dávid [2019]: A Brexit eddigi folyamata. Európai jog, 19. évf., 1. sz., 12-22. o.

Somai, Miklós - Biedermann, Zsuzsánna [2016]: Brexit: Reasons and challenges. Acta Oeconomica, Vol. 66., Special Issue, 137-156. o.

Swales, Kirby [2016]: Understanding the Leave vote. NetCan Social Research, London. Elérhető: http://whatukthinks.org/eu/wp-content/uploads/2016/12/NatCen_Brexplanations-report-FINALWEB2.pdf.

Tomlinson, Joe - Boyes, Kristi [2017]: UK Quo Vadis? The EEA As a Workable Framework (April 3, 2017). Elérhetö: SSRN, http://dx.doi.org/10.2139/ssrn.2946098.

Török Ádám [2017]: A brexit közbenső állapota. Közgazdasági Szemle, 64. évf., 1. sz., 1-16. o.

Watts, Joe [2017]: European Court decisions could still have direct force in UK after Brexit. Independent (23 August 2017). Elérhető: http://www.independent.co.uk/news/uk/politics/european-courtdecisions-uk-post-brexit-ecj-justice-eu-law-a7908216.html. 